\title{
Anaplasmataceae and Borrelia burgdorferi sensu lato in the sand lizard Lacerta agilis and co-infection of these bacteria in hosted Ixodes ricinus ticks
}

\author{
Anna Ekner ${ }^{1}$, Krzysztof Dudek ${ }^{1}$, Zofia Sajkowska ${ }^{1}$, Viktória Majláthová ${ }^{2}$, Igor Majláth² and Piotr Tryjanowski ${ }^{3 *}$
}

\begin{abstract}
Background: Anaplasmataceae and Borrelia burgdorferi s.l. are important tick-borne bacteria maintained in nature by transmission between ticks and vertebrate hosts. However, the potential role of lizards as hosts has not been sufficiently studied.

Results: The current study showed that 23 of 171 examined sand lizards Lacerta agilis were PCR positive for Anaplasmataceae. The nucleotide sequences of the several selected PCR products showed 100\% homology with Anaplasma spp. found in Ixodes ricinus collected in Tunisia and Morocco (AY672415 - AY672420). 1.2\% of lizard collar scale samples were PCR positive for B. Iusitaniae. In addition, 12 of 290 examined I. ricinus were PCR positive for B. burgdorferi s.l. and 82 were PCR positive for Anaplasmatacea. The number of ticks per lizard and the number of ticks PCR positive for both microorganisms per lizard were strongly correlated. Moreover, we found a significant correlation between numbers of ticks infected with Anaplasmataceae and with B. burgdorferi s.l. living on the same lizard. However, there was no significant correlation between detection of both bacteria in the same tick.
\end{abstract}

Conclusions: To the best of our knowledge, this is the first report of Anaplasmataceae DNA and additionally the second report of B. burgdorferi s.I DNA detection in the sand lizard.

Keywords: Tick-borne pathogens, Reptiles, Mixed infection, Lacertidae, Co-occurence

\section{Background}

One of the most widespread bacterium transmitted by ticks is Borrelia burgdorferi s. l., an agent of Lyme borreliosis [1,2]. Reservoirs of $B$. burgdorferi s.l. are vertebrates and special associations between Borrelia strains and particular groups of vertebrate hosts have been reported [3]. B. lusitaniae was the most common strain detected in lizard species and in ticks feeding on them [4-6].

Ticks are the main vector of other microorganisms, such as intracellular bacteria from the family Anaplasmataceae $[7,8]$, which attract the attention of public health professionals worldwide. One of the most

\footnotetext{
* Correspondence: piotr.tryjanowski@gmail.com

${ }^{3}$ Institute of Zoology, Poznań University of Life Sciences, Wojska Polskiego 71 c, 60-625 Poznań, Poland

Full list of author information is available at the end of the article
}

important species of this family is Anaplasma phagocytophilum which causes human anaplasmosis (HA), formerly known as a human granulocytic ehrlichiosis (HGE) $[9,10]$. A. phagocytophilum is an obligate intracellular bacterium infecting the neutrophils of various mammalian species [9]. Anaplasmataceae are maintained in nature by transmission between vectors and reservoirs. Reservoirs of the bacteria are vertebrates, mainly rodents and ruminants $[11,12]$. The potential role of reptiles as hosts or reservoirs is not known and has not been sufficiently evaluated. To date, despite being found in ticks feeding on reptiles [13-16], Anaplasma spp. has been detected only in three lizard species, Sceloporus ocidentalis, S. graciosus and Elgaria coeruleus, living in North America [13].

The most common species of ticks in Europe, Ixodes ricinus [17] feeds on a wide variety of vertebrate hosts,

\section{Biomed Central}


such as mammals and birds [8,18-22]. It also parasitises reptile species, and larvae and nymphs often feed on lizards [5,23-26]. I. ricinus may be infected simultaneously with different combinations of bacteria [10,27-29]. Observed microorganism co-infection rates suggest that the risk of infection with one tick-borne bacterium is not independent of other bacteria [30]. There are only a few studies on co-infection of bacteria in wild vector or host populations [31,32]. In addition, as far as we are aware, there has been only one study on co-infection of Anaplasmataceae and B. burgdorferi s.l. in ticks feeding on lizard species, moreover, on Lacerta viridis [16].

In this paper we show the role of sand lizard (Lacerta agilis) in the transmission cycle of important tick-borne pathogens, Anaplasmataceae and Borrelia burgdorferi s. 1. Moreover, we found a significant correlation between numbers of ticks infected with Anaplasmataceae and with $B$. burgdorferi s.l. living on the same lizard.

\section{Results}

290 ticks (176 nymphs and 114 larvae) were found in 69 of 171 (40.4\%, 95\% CL: 32.9 - 48.1) examined lizards. All of them were identified as I. ricinus. B. burgdorferi s. 1. DNA was detected in 12 of 290 ticks $(4.1 \%, 95 \%$ CL: 2.2 - 7.1; Table 1) taken from 10 lizards (5.9\%, 95\% CL: 2.8 - 10.5; Table 2). B. lusitaniae DNA was detected in 8 ticks $(66.7 \%$, 95\% CL: 34.9 - 90.1), B. burgdorferi s.s. DNA in 2 ticks $(16.7 \%$, 95\% CL: 02.1 - 48.4), the remaining two strains were not determined in RFLP analyses (Table 1). Among 171 examined lizards (43 adult females, 59 adult males, 26 sub-adults, 43 juveniles), 2 individuals ( 1 female, 1 sub-adult; $1.2 \%, 95 \%$ CL: 0.1 - 4.1) were PCR positive for B. lusitaniae. Both of them had ticks at the time of collection (Table 3). No other Borrelia strains DNA were detected in lizard collar scales. The number of ticks per lizard was strongly positively correlated with the number of ticks PCR positive for B. burgdorferi s.l. $(\mathrm{r}=0.57, \mathrm{n}=171, \mathrm{p}<0.0001$; Figure 1).

Anaplasmataceae DNA was detected in 82 (52 nymphs, 30 larvae) of 290 ticks (28.3\%, 95\% CL: 23.2 33.8; Table 1) taken from 29 lizards $(17.0 \%, 95 \%$ CL: 11.7 - 23.4; Table 2). In the body scales of 171 examined lizards Anaplasmataceae DNA was detected in 23 individuals $(13.4 \%, 95 \% \mathrm{CL}=8.7-19.5)$. Obtained sequences of several PCR products showed 100\% homology to each other. The sequence was compared with GenBank entries by Blast N2.2.13 and revealed $100 \%$ homology with Anaplasma spp. strains found in I. ricinus ticks collected on vegetation in Tunisia and Morocco (AY672415 - AY672420). Among the 23 lizards (14 males, 8 females, 1 sub-adult) PCR positive for Anaplasmataceae in the skin, 15 had no ticks (65.2\%, 95\% CL: $42.7-83.6)$ at the time of collection (Table 3). However, lizards that were PCR positive for Anaplasmataceae had a higher average number of ticks (mean \pm SE; $5.0 \pm 2.2$ ) compared to lizards PCR negative for Anaplasmataceae $(1.2 \pm 0.2$; U-test, $\mathrm{Z}=-2.51, \mathrm{p}$ $=0.012$ ), as well as a higher number of ticks PCR positive for Anaplasmataceae ( $2.2 \pm 1.0$ vs. $0.2 \pm 0.1$; U-test, $\mathrm{Z}=-2.68, \mathrm{p}=0.007)$. The number of ticks per lizard and the number of ticks PCR positive for Anaplasmataceae per lizard were strongly correlated $(\mathrm{r}=0.73, \mathrm{n}=$ $171, \mathrm{p}<0.001$; Figure 2).

Kendall's tau coefficient shows that the number of ticks PCR positive for Anaplasmataceae were strongly correlated with the number of ticks PCR positive for $B$. burgdorferi s.l. $(\mathrm{r}=0.42, \mathrm{n}=171, \mathrm{p}<0.0001)$ feeding on the same lizard. $6(2.1 \%, 95 \% \mathrm{CL}=0.8-04.5)$ ticks contained both B. burgdorferi s.l. and Anaplasmataceae DNA. However, Kendall's tau coefficient showed no significant correlation between detection of $B$. burgdorferi s.l. and Anaplasmataceae DNA $(\mathrm{r}=0.10, \mathrm{n}=290, \mathrm{p}=$ $0.088)$ in the same tick.

The co-infection index (Ic) for interactions between $B$. burgdorferi s.l. and Anaplasmataceae was 0.75. However, the difference between the number of obtained and expected co-infections was not significant $\left(\chi^{2}=0.02\right.$, $\mathrm{p}$ $=0.89)$. This suggested that there was no significant association between the bacteria.

We could not analyse a co-infection in lizards, because of too the small sample of lizards PCR positive for Borrelia burgdorferi s.l.

\section{Discussion}

Lizards as hosts of ticks are exposed to various tickborne pathogens. Previous studies have showed that reptiles are included in transmission cycles of $B$. burgdorferi s. 1. $[4,5,33]$. In our study, B. lusitaniae DNA was

Table 1 Number of ticks PCR positive for B. burgdorferi s.l. and Anaplasmataceae.

\begin{tabular}{|c|c|c|c|}
\hline & & $\begin{array}{l}\text { ticks collected from the lizards } \\
290\end{array}$ & \\
\hline & $\begin{array}{l}\text { ticks infected with Borrelia } \\
12\end{array}$ & & $\begin{array}{l}\text { ticks infected with Anaplasmataceae } \\
82\end{array}$ \\
\hline $\begin{array}{c}\text { ticks infected with B. lusitanieae } \\
8\end{array}$ & $\begin{array}{c}\text { ticks infected with } B \text {. burgdorferi s.s. } \\
2\end{array}$ & $\begin{array}{c}\text { ticks infected with } B \text {. burgdorferi s.l. } \\
44\end{array}$ & \\
\hline
\end{tabular}


Table 2 Number of lizards with and without ticks PCR positive for Borrelia and Anaplasmataceae.

\begin{tabular}{|c|c|c|c|}
\hline $\begin{array}{l}\text { lizards without ticks } \\
102\end{array}$ & & $\begin{array}{c}\text { lizards with ticks } \\
69\end{array}$ & \\
\hline & $\begin{array}{l}\text { lizards infected with Anaplasmataceae } \\
29\end{array}$ & $\begin{array}{c}\text { lizards infected with Borrelia } \\
10\end{array}$ & $\begin{array}{c}\text { lizards non-infected } \\
30\end{array}$ \\
\hline
\end{tabular}

detected in $1.2 \%$ of lizards. Compared with other papers, this is a low infestation $[4,5]$. However, this is only the second detection of the bacterium in sand lizards [4] and the third detection of the B. lusitaniae strain in Poland $[6,34]$. In all lizards, as well in most of the ticks, $B$. lusitaniae was detected, which confirms the connection of this strain with reptile species $[3,35,36]$.

During the study $28.3 \%$ of ticks feeding on lizards were infected with Anaplasmataceae. This is high compared to other studies on ticks from lizard species $[13,14,16]$. However, despite Anaplasma spp. DNA being previously detected in ticks collected from reptiles [14], it had only been detected in three lizard species, $S$. occidentalis, S. graciosus and Elgaria coeruleus [13]. In our study, 13.4\% of lizards were PCR positive for Anaplasmataceae. To the best of our knowledge this is the first detection of the bacterium in sand lizard, moreover, the first among lizards living in Europe, and only the fourth among lizards worldwide. In addition, the previous report concerned $10.2 \%$ of lizards living in California which were infected with A. phagocytophilum [13]. In presented study, some lizards were PCR positive for different species of Anaplasmataceae than in the previous study on reptiles [13], namely Anaplasma spp. $100 \%$ homology with strains found in I. ricinus collected on vegetation in Tunisia and Morocco (AY672415 AY672420) [37]. The pathogen could be transferred to Poland together with exotic reptiles or other animals [14]. On the other hand, lizards could not be analysed for presence of that species before.

Lizards PCR positive for Anaplasmataceae had more ticks than non infected individuals. Moreover, the number of ticks feeding on a lizard was strongly correlated with both the number of ticks PCR positive for Anaplasmataceae and PCR positive for B. burgdorferi s.l. It may result from that the more the lizard has ticks, the more

Table 3 Number of lizards PCR positive for B. burgdorferi s.l. and Anaplasmataceae and presence of ticks in lizards with the bacteria during the time of collection.

\begin{tabular}{|c|c|c|c|}
\hline \multicolumn{4}{|c|}{$\begin{array}{l}\text { lizards cached during the study } \\
\qquad 171\end{array}$} \\
\hline lizards infecte & d with Borrelia & $\begin{array}{r}\text { lizards i } \\
\text { Anaplc }\end{array}$ & $\begin{array}{l}\text { nfected with } \\
\text { ismataceae } \\
23\end{array}$ \\
\hline $\begin{array}{c}\text { zards with ticks } \\
2\end{array}$ & $\begin{array}{c}\text { lizards without } \\
\text { ticks } \\
0\end{array}$ & $\begin{array}{l}\text { lizards with ticks } \\
8\end{array}$ & $\begin{array}{l}\text { lizards without ticks } \\
15\end{array}$ \\
\hline
\end{tabular}

chance it has ticks with bacteria. Such correlations suggest that the more ticks feed on a lizard, the greater chance of contact with infected ticks, and hence more chance of acquiring tick-borne infection. The results confirmed previous studies $[38,39]$ which show that the probability of host exposure to a tick-borne pathogen is correlated with tick abundance. Therefore, the best way to avoid infection with tick-borne disease is to avoid areas with a high density of its vectors [18].

Ticks can be infected with two or more microorganisms simultaneously $[16,38,40,41]$, but relationships between them in ticks can be varied. Some of them display antagonistic interactions, others positive, and many evidently do not interact [38]. Interpretation of the results can be difficult, because many factors, other than simply interaction between microorganisms, may influence the number of co-infections. In addition, the occurrence of tick-borne pathogens in nature may be influenced by a number of factors, such as microclimate conditions, vegetation, and tick density [42]. In the present study we did not show any correlation between detection of B. burgdorferi s.l. and Anaplasmataceae, occurring in the same ticks. The results may suggest a lack of interaction between the bacteria. These results are in contrast to those obtained by Václav [16], where Anaplasmataceae had a negative influence on $B$.

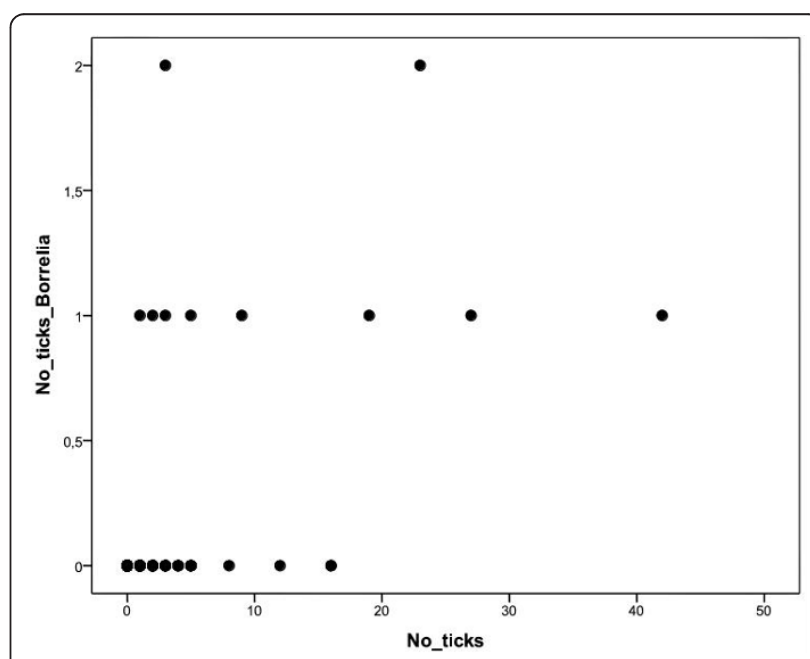

Figure 1 Correlation between total number of ticks and the ticks PCR positive for B. burgdorferi s.I. Positive correlation between the number of the ticks feeding on a lizard and the number of the ticks PCR positive for B. burgdorferi s.l. $(r=0.57, n=$ $171, p<0.0001)$. 


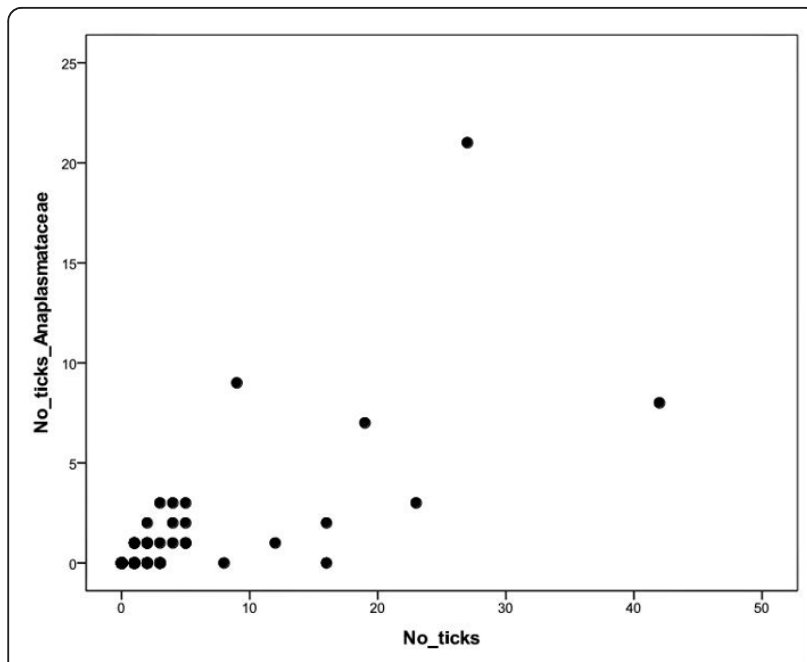

Figure 2 Correlation between total number of ticks and the ticks PCR positive for Anaplasmataceae. Positive correlation between the number of the ticks feeding on a lizard and the number of the ticks PCR positive for Anaplasmataceae $(r=0.73, n=$ $171, p<0.001)$

lusitaniae. However, in the same study, B. lusitaniae positively influenced Anaplasmataceae prevalence, and co-infection of both bacteria in ticks was higher than expected [16]. To the best of our knowledge, the present work is the first study of mixed infection of B. burgdorferi s.l. and Anaplasmataceae DNA in ticks feeding on L. agilis [16]. Knowledge of the multiple infection is very important for public health, especially for a correct diagnosis and prophylaxis of tick-borne diseases, as well as prognosis of mixed infection in humans. Moreover, hosts infected by several different pathogens can have different symptoms of a disease [43]. Knowledge about the local occurrence of pathogens may be useful when disease symptoms of patients bitten in that locality are unclear [10]. It is important to know how the bacteria can coexist in individual ticks as a prerequisite for the occurrence of co-transmission from tick to the host [30].

In our study, $65.2 \%$ of 23 lizards PCR positive for Anaplasmataceae did not have any ticks at the time of collection, which may suggest that this bacterium is maintained in a lizard body longer than the source of the infection. However, we still do not know if lizards are reservoirs of Anaplasmataceae or just have organisms deposited in them by infected ticks. A previous study, where the author experimentally infected lizards with the bacterium, concluded that lizards were not reservoir hosts for Anaplasma phagocytophilum [13]. However, it does not mean that lizards cannot be a reservoir of the other species of Anaplasmataceae. Moreover, lizards may influence the transmission cycle of bacteria in areas where there are significant hosts for ticks [2].

\section{Conclusions}

To the best of our knowledge, the current study is the first report of Anaplasmataceae DNA, and the second report of B. burgdorferi s.l DNA detection in a European lizard species, namely the sand lizard Lacerta agilis. Obtained results suggest that lizards may be a reservoirs of this pathogen and can influence the transmission cycle of the bacteria in some areas. Moreover, we found a significant correlation between numbers of ticks infected with Anaplasmataceae and with B. burgdorferi s.l. living on the same lizard. This knowledge may be important in the estimation of the dispersion of the tick-borne pathogen and/or sources of potential human infection.

\section{Materials and methods}

\section{Study area and the study species}

The study was carried out in March - September in 2008 and 2009 in an extensive farmland area in the Barycz valley, in Poland $\left(51^{\circ} 34^{\prime} \mathrm{N}, 17^{\circ} 40^{\prime} \mathrm{E}\right.$, elevation 110 $170 \mathrm{~m}$ ). This study area is characterised by intensively farmed land with a varied mosaic of arable fields, meadows, small woodlots and scattered trees and shrubs of different ages, dominated by white willow Salix fragilis, silver birch Betula pendula, black poplar Populus nigra and pine Pinus silvestris. It contains both dry sandy areas and moist areas (for details see reference [44]).

The sand lizard is a short-legged, rather robust, small to medium sized lizard (up to $110 \mathrm{~mm}$ snout to vent length (SVL)) from the family Lacertidae. It is a grounddwelling and strongly diurnal species with one of the widest distribution ranges of all reptiles [45]. In the study area the sand lizard is a common species, and an average of 0.37 individuals were noted on $200 \mathrm{~m}$ transect route [44].

\section{Lizard and tick sampling}

Lizards were captured using landing fishnets or by hand, then aged (adult, sub-adult and juvenile) and sexed. Animals were examined for the presence of ticks, which were removed with forceps and stored in $70 \%$ ethanol. Ticks were identified to species and aged using a binocular microscope, according to Siuda [17].

From each individual lizard a skin biopsy was taken from collar scales (3-4 $\mathrm{mm}$ in length) with sterile scissors and put in separate vials with $70 \%$ ethanol. This method had been previously successfully used to detect tick-borne pathogens in reptiles [4,5]. The collar is an extension of the skin, hence this method is only minimally invasive to the lizard. The sample is also easy to obtain. To avoid resampling the same individual, lizards 
were permanently marking using Medical Cautery Units (unpublished observations).

Lizard capture was carried out according to Polish law and the ethical commission for the study on animals (LKE 12/2007).

\section{DNA isolation}

Immediately prior to extraction, ticks and tissues were dried for $30 \mathrm{~min}$ to evaporate the ethanol. Each sample was cut with a disposable sterile scalpel. Genomic DNA from lizard scales and from ticks was isolated by alkaline hydrolysis, according to previous reference [46], with a $30 \mathrm{~min}$. incubation time. Cut samples were incubated in the presence of $100 \mu \mathrm{l}$ ammonium hydroxide $(0,5 \mathrm{~mol} / \mathrm{l})$ at $100^{\circ} \mathrm{C}$ for 30 minutes in $1.5 \mathrm{ml}$ tube, followed by 10 minutes at $100^{\circ} \mathrm{C}$ with the tube open. Isolated DNA was stored at $-20^{\circ} \mathrm{C}$.

\section{Polymerase Chain Reaction (PCR)}

PCR amplification was performed in a total of $25 \mu \mathrm{l}$ reaction mixture of a MasterTaq DNA polymerase kit (Eppendorf AG, Hamburg, Germany) containing $10.4 \mu \mathrm{l}$ of deionized water, $5.0 \mu \mathrm{l}$ of $5 \times$ TaqMaster PCR Enhancer, $2.5 \mu \mathrm{l}$ of $10 \times$ Taq buffer (with $15 \mathrm{mM} \mathrm{Mg}^{2+}$ ), $1.5 \mu \mathrm{l}$ of a $25 \mathrm{mM}$ solution of $\mathrm{Mg}(\mathrm{OAc}) 2,0.1 \mu \mathrm{l}$ of Taq DNA polymerase $(5 \mathrm{U} / \mathrm{ml}), 0.5 \mu \mathrm{l}$ of dNTP-mix $(10 \mathrm{mM})$ (Fermentas, Vilnius, Lithuania), $1.25 \mu \mathrm{l}$ of each primer (10 pmole/ $\mu \mathrm{l}$ ) (Invitrogen, Paisley, Scotland), and $2.5 \mu \mathrm{l}$ of DNA template.

In order to verify that DNA had been successfully isolated from each tick, primers for the fragment of the tick's mitochondrial cytochrome $b$ gene $(620 \mathrm{bp})$ were used [47]. Verification of successfully isolated DNA from lizard scales was carried out using primers for the fragment of the vertebrate's $12 \mathrm{~S}$ rDNA [48]. Seven negative samples of ticks and two negative samples of lizards were excluded from further analysis.

Samples with successfully isolated DNA of ticks and lizard were examined for the presence of Anaplasmataceae DNA by amplifying a portion of the region of the 16S (rrs) rRNA gene of the family Anaplasmataceae $[37,49]$. Samples were also examined for the presence of $B$. burgdorferi s.l. by amplifying a portion of the $5 \mathrm{~S}$ (rrfA)-23S ( rrlB) rDNA intergenic spacer [50]. The PCR products were electrophoresed on a $1 \%$ agarose gel, stained with Gold View Nucleic Acid Stain, and visualized with a UV transilluminator.

\section{RFLP analysis}

The positive PCR products of the 5S-23S rDNA intergenic spacer regions were further analyzed by RFLP. Previously extracted DNA of $B$. afzelii, B. garinii, $B$. valaisiana, $B$. burgdorferi s.s. and B. lusitaniae were used as positive controls. For each positive sample $13 \mu \mathrm{l}$ of amplified DNA were digested at $65^{\circ} \mathrm{C}$ overnight in a solution containing $5 \mathrm{U}$ of Tru1 $\mathrm{I}(300 \mathrm{u} / \mathrm{ml})$ and $1 \times$ Buffer R (Fermentas). Electrophoresis was carried out in $16 \%$ polyacrylamide gel at $150 \mathrm{~V}$ for $3 \mathrm{~h}$. The gels were stained with SYBR Gold nucleic acid gel stain (Molecular Probes, Leiden, The Netherlands) for $20 \mathrm{~min}$, and bands were visualized with a UV transilluminator.

All procedures, DNA isolation, PCR, and electrophoresis were performed in separate rooms using different pipettes and racks, with separate lab coats and disposable gloves worn in each laboratory to prevent carry-over contamination and to avoid false-positive results. PCR mixture was prepared in a sterile PCR box. All liquid handling procedures were performed using disposable sterile filter tips. In each DNA isolation and PCR reaction, a negative control (water) was included.

\section{DNA sequencing of PCR products}

Three randomly selected PCR products of $16 \mathrm{~S}$ rDNA of the Anaplasmataceae family were sequenced in the Laboratory of Biomedical Microbiology and Immunology at the University of Veterinary Medicine and Pharmacy in Košice. Sequencing only a few selected samples to exactly verify a bacterium species is an acceptable procedure [14]. Prior to the sequencing, PCR products were purified using a QIAquick PCR purification kit (Qiagen). The complementary strands of each sequenced product were manually assembled.

\section{Index of co-infection $\left(I_{c}\right)$}

Ginsberg [38] developed an index of co-infection $\left(\mathrm{I}_{\mathrm{c}}\right)$, which quantify the degree of departure of the number of mixed infections from independence. This is defined as the difference of the number of co-infections from the number expected due to chance alone, as a percentage of the total number of infected ticks in the sample.

$$
\mathrm{I}_{\mathrm{C}}=[(\mathrm{O}-\mathrm{E}) / \mathrm{N}] \times 100,
$$

where: $\mathrm{O}=$ number of observed coinfections, $\mathrm{E}=$ expected number of co-infected ticks due to chance alone, $\mathrm{N}=$ total number of ticks infected by either or both microorganisms.

$$
\begin{aligned}
& \mathrm{E}=[(\mathrm{a}+\mathrm{b})(\mathrm{a}+\mathrm{c})] /(\mathrm{a}+\mathrm{b}+\mathrm{c}+\mathrm{d}), \\
& \mathrm{N}=\mathrm{a}+\mathrm{b}+\mathrm{c},
\end{aligned}
$$

where: $\mathrm{a}=$ number of ticks infected with both bacteria (equals $\mathrm{O}$ ), $\mathrm{b}=$ number of ticks infected only with microorganism $1, \mathrm{c}=$ number of ticks infected only with microorganism 2, and $\mathrm{d}=$ number of ticks not infected with either microorganism. Ic is positive when the number of co-infections is greater than expected, and negative when there are fewer co-infections than would be 
expected due to chance alone. Significance of the index was calculated by a chi-square test.

\section{Statistical analysis}

To improve sample size and show more general patterns, data from the two breeding seasons (2008 and 2009) were pooled. Statistics were performed using SPSS for Windows, and all tests are two-tailed. Confidence limits (95\% CL) for binary, presence-absence, data were calculated in an Excel macro.

\section{Acknowledgements}

We would like to thank all those who helped us in the field and laboratory, especially Víchová B. and Pet́ko B. Tim Sparks critically read previous versions of the manuscript. We would like to thank Howard S. Ginsberg for discussion on the co-infection index.

This work was supported by grants N N 303317433 and N N 304381338 from the Ministry of Science and Higher Education of Poland. A. E. is a scholar of Adam Mickiewicz University Foundation in 2011.

\section{Author details}

${ }^{1}$ Department of Behavioural Ecology, Adam Mickiewicz University, Umultowska 89, 61-614 Poznań, Poland. ²Parasitological Institute, Slovak Academy of Sciences, Hlinkova 3, 040-01 Košice, Slovakia. ${ }^{3}$ Institute of Zoology, Poznań University of Life Sciences, Wojska Polskiego 71 c, 60-625 Poznań, Poland.

\section{Authors' contributions}

AE collected data, performed field and laboratory work, analysed data and wrote initial draft. KD and ZS collected data and performed field and laboratory work. PT analysed data and wrote initial draft. VM and IM supervised the laboratory work and intellectually support the study. All authors read and approved the final manuscript.

\section{Competing interests}

The authors declare that they have no competing interests.

Received: 10 August 2011 Accepted: 20 September 2011 Published: 20 September 2011

\section{References}

1. Levin ML, des Vignes F, Fish D: Disparsity in the natural cycles of Borrelia burgdorferi and the agent of human granulocytic ehrlichiosis. Emer Infect Dis 1999, 5:204-208.

2. Ragagli C, Bertolotti L, Giacobini M, Mannelli A, Bisanzio D, Amore G, Tomassone L: Transmission Dynamics of Borrelia lusitaniae and Borrelia afzelii Among Ixodes ricinus, Lizards, and Mice in Tuscany, Central Italy. Vector-Borne Zoonot 2009, 9:1-8.

3. Richter D, Matuschka FR: Perpetuation of the Lyme Disease Spirochete Borrelia lusitaniae by Lizards. Appl Environ Microbiol 2006, 72:4627-4632.

4. Földvári G, Rigó K, Majláthová V, Majláth I, Farkas R, Pet’ko B: Detection of Borrelia burgdorferi sensu lato in lizards and their ticks from Hungary. Vector-Borne Zoonot 2009, 9:331-336.

5. Majláthová V, Majláth I, Derdáková M, Víchová B, Pet'ko B: Borrelia lusitaniae and Green Lizards (Lacerta viridis), Karst Region, Slovakia. Emerg Infect Dis 2006, 12:1895-1901.

6. Majláthová V, Majláth I, Hromada M, Tryjanowski P, Bona M, Antczak M, Víchová B, Dzimko Š, Mihalca A, Pet'ko B: The role of the sand lizard (Lacerta agilis) in the transmission cycle of Borrelia burgdorferi sensu lato. Int J Med Microbiol 2008, 298:161-167.

7. Derdakova M, Halanova M, Stanko M, Štefančíková A, Čislakova L, Pet́kov B: Molecular evidence for Anaplasma phagocytophilum and Borrelia burgdorferi sensu lato in Ixodes ricinus ticks from Eastern Slovakia. Ann Agric Environ Med 2003, 10:269-271.

8. Skoracki M, Michalik J, Skotarczak B, Rymaszewska A, Sikora B, Hofman T, Wodecka B, Sawczuk M: First detection of Anaplasma phagocytophilum in quill mites (Acari: Syringophilidae) parasitizing passerine birds. Microbes Infect 2006, 8:303-307.

9. Dumler JS, Barbet AF, Bekker CPJ, Dasch GA, Palmer GH, Ray SC, Rikihisa Y, Rurangirwa FR: Reorganisation of genera in the families Rickettsiaceae and Anaplasmataceae in the order Rickettsiales: unification of some species of Ehrlichia with Anaplasma, Cowdria with Ehrlichia and Ehrlichia with Neorickettsia, descriptions of six new species combinations and designation of Ehrlichia equi and "HGE agent" as subjective synonymus of Ehrlichia phagocytophila. Int J Syst Evol Microbiol 2001, 51:2145-2165.

10. Stańczak J, Gabre RM, Kruminis-Łozowska W, Racewicz M, Kubica-Biernat B: Ixodes ricinus as a vector of Borrelia burgdorferi sensu lato, Anaplasma phagocytophilum and Babesia microti in urban and suburban forests. Ann Agric Environ Med 2004, 11:109-114.

11. Alberdi MP, Walker AR, Urquhart KA: Field evidence that roe deer (Capreolus capreolus) are a natural host for Ehrlichia phagocytophila. Epidemiol Infect 2000, 124:315-323.

12. Zhan L, Cao WC, Jiang JF, Zhang XA, Liu YX, Wu XM, Zhang WY, Zhang PH, Bian CL, Dumler JS, Yang H, Zuo SQ, Chu CY, Liu W, Richardus JH, Habbema JDF: Anaplasma phagocytophilum from rodents and sheep, China. Emerg Infect Dis 2010, 16:764-768.

13. Nieto NC, Foley JE, Bettaso J, Lane RS: Reptile infection with Anaplasma phagocytophilum, the causitive agent of granulocytic anaplasmosis. $J$ Parasitol 2009, 95:1165-1170.

14. Nowak M, Cieniuch S, Stańczak J, Siuda K: Detection of Anaplasma phagocytophilum in Amblyomma flavomaculatum ticks (Acari: Ixodidae) collected from lizard Varanus exanthematicus imported to Poland. Exp Appl Acarol 2010, 51:363-371.

15. Tijsse-Klasen E, Fonville M, Reimerink JHJ, Spitzen A, Sprong H: Role of sand lizards in the ecology of Lyme and other tickborne diseases in the Netherlands. Parasit Vectors 2010, 3:42.

16. Václav R, Ficová M, Prokop P, Betáková T: Associations Between Coinfection Prevalence of Borrelia lusitaniae, Anaplasma sp., and Rickettsia sp. in Hard Ticks Feeding on Reptile Hosts. Microb Ecol 2010, 61:245-253.

17. Siuda K: In Ticks (Acari: Ixodida) of Poland. Taxonomy and Distribution. Volume 2. Warsaw: Polish Parasitological Society; 1993, (in Polish).

18. Bjöersdorff A, Bergström S, Massung RF, Haemig PD, Olsen B: Ehrlichiainfected ticks on migrating birds. Emerg Infect Dis 2001, 7:877-879.

19. Eisen L, Eisen RJ, Lane RS: The roles of birds, lizards, and rodents as hosts for the western black-legged tick Ixodes pacificus. J Vector Ecol 2004, 29:295-308.

20. Skotarczak B, Rymaszewska A, Wodecka B, Sawczuk M, Adamska M, Maciejewska A: PCR detection of granulocytic Anaplasma and Babesia in Ixodes ricinus ticks and birds in west-central Poland. Ann Agric Environ Med 2006, 13:21-23.

21. Slowik TJ, Lane RS: Feeding preferences of the immature stages of three western North American ixodid ticks (Acari) for avian, reptilian, or rodent hosts. J Med Entomol 2009, 46:115-122

22. Abd Rani PAM, Irwin PJ, Coleman GT, Gatne M, Traub RJ: A survey of canine tick-borne diseases in India. Parasit Vectors 2011, 4:141.

23. Bauwens D, Strijbosch H, Stumpel AHP: The lizards Lacerta agilis and $L$. vivipara as hosts to larvae and nymphs of the tick Ixodes ricinus. Holarctic Ecol 1983, 6:32-40.

24. Clark K, Hendricks A, Burge D: Molecular Identification and analysis of Borrelia burgdorferi sensu lato in lizards in the Southeastern United States. Appl Environ Microb 2005, 71:2616-2625.

25. Gryczyńska-Siemiątkowska A, Siedlecka A, Stańczak J, Barkowska M: Infestation of sand lizards (Lacerta agilis) resident in the Northeastern Poland by Ixodes ricinus (L.) ticks and their infection with Borrelia burgdorferi sensu lato. Acta Parasitol 2007, 52:165-170.

26. Lane RS, Loye JE: Lyme diseases in California: interrelationship of Ixodes pacificus (Acari: Ixodidae), the Western Fence Lizard (Sceloporus occidentalis), and Borrelia burgdorferi. J Med Entomol 1989, 26:272-278.

27. Schorn S, Pfister K, Reulen H, Mahling M, Silaghi C: Occurrence of Babesia spp., Rickettsia spp. and Bartonella spp. in Ixodes ricinus in Bavarian public parks, Germany. Parasit Vectors 2011, 4:135.

28. Sun J, Liu Q, Lu L, Ding G, Guo J, Fu G, Zhang J, Meng F, Wu H, Song X, Ren D, Li D, Guo Y, Wang J, Li G, Liu J, Lin H: Coinfection with Four Genera of Bacteria (Borrelia, Bartonella, Anaplasma, and Ehrlichia) in Haemaphysalis longicornis and Ixodes sinensis Ticks from China. VectorBorne Zoonotic Dis 2008, 8:791-796. 
29. Wójcik-Fatla A, Szymańska J, Wdowiak L, Buczek A, Dutkiewicz J: Coincidence of three pathogens (Borrelia burgdorferi sensu lato, Anaplasma phagocytophilum and Babesia microti) in Ixodes ricinus ticks in the lublin macroregion. Ann Agric Environ Med 2009, 16:151-158.

30. Alekseev AN, Dubinina HV, Jushkova OV: First report on the coexistence and compatibility of seven tickborne pathogens in unfed adult Ixodes persulcatus Schulze (Acarina: Ixodidae). Int J Med Microbiol 2004, 37:104-108.

31. Dib L, Bitam I, Tahri M, Bensouilah M, De Meeûs T: Competitive exclusion between Piroplasmosis and Anaplasmosis agents within Cattle. PloS Pathog 2008, 4:e7.

32. Nieto NC, Foley JE: Meta-analysis of coinfection and coexposure with Borrelia burgdorferi and Anaplasma phagocytophilum in humans, domestic animals, wildlife, and Ixodes ricinuscomplex ticks. Vector-Borne Zoonotic Dis 2009, 9:93-102

33. Giery ST, Ostfeld RS: The role of lizards in the ecology of Lyme disease in two endemic zones of the Northeastern United States. J Parasitol 2007, 93:511.

34. Wodecka B, Skotarczak B: First isolation of Borrelia lusitaniae DNA from Ixodes ricinus ticks in Poland. Scand J Infect Dis 2005, 37:27-34.

35. Amore G, Tomassone L, Grego E, Ragagli C, Bertolotti L, Nebbia P, Rosati S, Mannelli A: Borrelia lusitaniae in Immature Ixodes ricinus (Acari: Ixodidae) Feeding on Common Wall Lizards in Tuscany, Central Italy. J Med Entomol 2007, 44:303-307.

36. Dsouli N, Younsi-Kabachii H, Postic D, Nouira S, Gern L, Bouattour A: Reservoir role of lizard Psammodrus algirus in transmission cycle of Borrelia burgdorferi sensu lato (Spirochaetaceae) in Tunisia. $J$ Med Entomol 2006, 43:737-742.

37. Sarih M, M'Ghirbi Y, Bouattour A, Gern L, Baranton G, Postic D: Detection and identification of Ehrlichia spp. in ticks collected in Tunisia and Morocco. J Clin Microbiol 2005, 43:1127-1132.

38. Ginsberg HS: Potential effects of mixed infections in ticks on transmission dynamics of pathogens: comparative analysis of published records. Exp Appl Acarol 2008, 46:29-41.

39. Ginsberg HS: Transmission risk of Lyme disease and implications for tick management. Am J Epidemiol 1993, 138:65-73.

40. Dietrich F, Schmidgen T, Maggi RG, Richter D, Matuschka FR, Vonthein R, Breitschwerdt EB, Kempf VAJ: Prevalence of Bartonella henselae and Borrelia burgdorferi Sensu Lato DNA in Ixodes ricinus Ticks in Europe. Appl Environ Microbiol 2010, 76:1395-1398.

41. Schouls LM, Van De Pol I, Rijpkema SG, Schot CS: Detection and Identification of Ehrlichia, Borrelia burgdorferi Sensu Lato, and Bartonella Species in Dutch Ixodes ricinus Ticks. J Clin Microbiol 1999, 37:2215-2222.

42. Hildebrandt A, Schmidt KH, Wilske B, Dorn W, Straube E, Fingerle V: Prevalence of Four Species of Borrelia burgdorferi Sensu Lato and Coinfection with Anaplasma phagocytophila in Ixodes ricinus Ticks in Central Germany. Eur J Clin Microbiol Infect Dis 2003, 22:364-367.

43. Krause PJ: Babesiosis. Med Clin N Am 2002, 86:361-373.

44. Ekner A, Majlath I, Majlathova V, Hromada M, Bona M, Antczak M, Bogaczyk M, Tryjanowski P: Densities and morphology of two co-existing lizard species (Lacerta agilis and Zootoca vivipara) in extensively used farmland in Poland. Folia Biol 2008, 56:165-171.

45. Bischoff W: Lacerta agilis Linnaeus, 1758, Zauneidechse. In Handbuch der Reptilien und Amphibien Europas. Volume 2. Edited by: Böhme W. Germany: Aula Verlag; 1984:23-68.

46. Guy EC, Stanek G: Detection of Borrelia burgdorferi in patients with Lyme disease by the polymerase chain reaction. J Clin Pathol 1991, 44:610-611.

47. Black WC, Roehrdanz RL: Mitochondrial gene order is not conserved in arthropods: prostriate and metastriate tick mitochondrial genomes. Mol Biol Evol 1998, 15:1772-1785.

48. Humair PF, Douet V, Morán Cadenas F, Schouls LM, Van De Pol I, Gern L: Molecular identification of bloodmeal source in Ixodes ricinus ticks using $12 \mathrm{~S}$ rDNA as a genetic marker. J Med Entomol 2007, 44:869-880.

49. Pancholi P, Kolbert CP, Mitchell PD, Reed KD, Dumler JS, Bakken JS, Telford SR, Persing DH: Ixodes dammini as a potential vector of human granulocytic ehrlichiosis. J Infect Dis 1995, 172:1007-1012.

50. Derdakova M, Beati L, Pet'ko B, Stanko M, Fish D: Genetic variability within Borrelia burgdorferi sensu lato genospecies established by PCR-singlestrand conformation polymorphism analysis of the rrfA-rrlB intergenic spacer in Ixodes ricinus ticks from the Czech Republic. Appl Environ Microbiol 2003, 69:509-516. doi:10.1186/1756-3305-4-182

Cite this article as: Ekner et al:: Anaplasmataceae and Borrelia burgdorferi sensu lato in the sand lizard Lacerta agilis and co-infection of these bacteria in hosted Ixodes ricinus ticks. Parasites \& Vectors 2011 4:182.

\section{Submit your next manuscript to BioMed Central and take full advantage of:}

- Convenient online submission

- Thorough peer review

- No space constraints or color figure charges

- Immediate publication on acceptance

- Inclusion in PubMed, CAS, Scopus and Google Scholar

- Research which is freely available for redistribution

Submit your manuscript at www.biomedcentral.com/submit
C Biomed Central 